\title{
Perception and Attitude of Maxillofacial Surgeons towards in-Clinic Counselling on Tobacco Cessation in Tertiary Hospitals in Nigeria
}

\author{
Olasunkanmi Funmilola Kuye ${ }^{1}$, Olufemi Olagundoye ${ }^{2}$, \\ Adeola Mofoluwake Ladeji ${ }^{3}$, Mofoluwaso Abimbola Olajide ${ }^{4}$, \\ Adetayo Aborisade ${ }^{5}$, Adewale Francis Adejobi ${ }^{6}$, Olufemi Erinoso ${ }^{7}$, \\ Ademola Olaitan 8
}

${ }^{1}$ Faculty of Dentistry, Lecturer \& Consultant Oral \& Maxillofacial Surgeon, Lagos State University College of Medicine, Ikeja, Lagos

${ }^{2}$ Faculty of Dentistry, Lecturer \& Consultant Periodontologist, Lagos State University College of Medicine Ikeja, Lagos

${ }^{3}$ Faculty of Dentistry, Senior Lecturer \& Consultant Oral Pathologist, Lagos State University College of Medicine, Ikeja, Lagos

${ }^{4}$ Faculty of Dentistry, Lecturer \& Consultant Oral Pathologist, Lagos State University College of Medicine Ikeja, Lagos

${ }^{5}$ Faculty of Dentistry, Lecturer \& Consultant Oral Pathologist, Bayero University, Kano.

${ }^{6}$ Faculty of Dentistry, Lecturer \& Consultant Oral \& Maxillofacial Surgeon, Obafemi Awolowo University, Ile Ife, Osun State

${ }^{7}$ Senior Registrar, Lagos State University Teaching Hospitals, Ikeja, Lagos

${ }^{8}$ Professor \& Lecturer Oral \& Maxillofacial Surgeon, Lagos State University College of Medicine, Ikeja, Lagos

Corresponding Author: Olasunkanmi Funmilola Kuye

\begin{abstract}
Cigarettes and other forms of tobacco are known to be highly addictive, the use and production of which are on the rise. Tobacco use is a risk factor in the development of diseases especially oral cancer, affects negatively wound healing in maxillofacial surgical procedure, and periodontal therapies. Therefore, the need for tobacco cessation programs on patients among Maxillofacial surgeons and the trainees is necessary.

Objectives- This is to assess the perception, attitude, and the influence of age, gender, duration of practice, and environment/religion on the cessation counseling carried out by Oral \& Maxillofacial surgeons

Methods- A prospective questionnaire-based study. A survey was carried out by sending validated, structured self-administered pretested questionnaires to Oral and Maxillofacial Surgery trainees and specialists in tertiary hospitals in different parts (North, South, and West) of Nigeria. The questionnaire assessed perceptions and attitudes- of the respondent, as well as the influence of age, gender, duration of practice, and environment/religion on in-clinic tobacco cessation.

Results- A total of 44 individuals participated in the study. More respondents from senior registrars 19(43\%), and with the majority from the Teaching Hospital 33(75\%) out of the three cadres of institutions where the survey was done. Male to female ratio of respondents was $1: 2.1$, with the mean age of the participants 36.7. All agreed to the need for tobacco cessation counseling among Oral \& Maxillofacial surgeons, only $37(84.1 \%)$ believe that in-clinic counseling will significantly reduce the prevalence of oral cancer. Age groups, sex, religion, designation, and the years in practice have a significant relationship with the participant perception-related question $\mathrm{p}=0.001$, as well the like use of religious and professional techniques in counseling smokers $(p<0.05)$. The gender of study participants had a significant influence on their perception of the need for in-clinic tobacco cessation counseling.
\end{abstract}


Olasunkanmi Funmilola Kuye et.al. Perception and attitude of maxillofacial surgeons towards in-clinic counselling on tobacco cessation in tertiary hospitals in Nigeria.

Conclusion- Tobacco cessation program within the health institutions is tested and an affirmed avenue to stop or reduce the associated risk factors with substance use. Therefore, need for policymakers in health sectors to organize training programs for maxillofacial surgeons.

Keywords- Oral \& Maxillofacial surgeons, Tobacco cessation, attitude, and perceptions, in-clinic counseling

\section{INTRODUCTION}

Cigarettes are the most commonly used form of tobacco, other forms of tobacco formulation known include conventional smokeless tobacco; compressed dissolvable tobacco; cigars; tobacco pipes and water pipe cigarettes, and electronic cigarettes (e-cigarettes) (1,2). Smoked and smokeless forms of tobacco contain nicotine, a highly addictive chemical that makes quitting difficult for habituated tobacco users (1).

The use and production of tobacco had increased tremendously. It's the secondlargest production in the world $(2,3)$. Tobacco use is a substantial risk factor in the development and severity of diseases most especially oral cancer (4). Other oral manifestations often encountered within the oral environment include stains on teeth, halitosis, and premalignant lesions (5) The lung is considered to be at the highest relative risk for cancer due to smoking, other high relative risk structures are the larynx and oral cavity $(5,6)$ Tobacco also affects postoperative wound healing of surgical and nonsurgical tooth extractions, implants, maxillofacial surgeries procedures, and periodontal therapies $(7,8)$. Thus, the need for cessation of tobacco use. Tobacco counseling has been reported that with appropriate assistance and professional advice by health professionals can lead to a cessation rate of $10 \%-20 \%$ among users (6). Furthermore, it has been speculated that dentist's counseling on tobacco cessation coupled with pharmacotherapy use can double or triple success rates previously recorded (9).

Therefore, the importance of the effective role of maxillofacial surgeons in smoking cessation services and prevention in the tobacco epidemic, therefore, is an essential way to combat it and is very crucial given the impact of smoking on oral health $(2,10)$.

Maxillofacial surgeons come across patients with a lot of these conditions as oral cancers, precancer lesions, tissue discoloration, teeth stains, and do treat some of them on daily basis. This direct contact of the maxillofacial surgeons either in training or as specialists creates an enabling environment not only to treat but also an opportunity to play an important role by working through the health care system to motivate and advise users to quit through inclinic cessation counseling (11). This study aims to look at the perceptions and attitudes of maxillofacial surgeons in Nigeria on the in-clinic tobacco cessation counseling and effects of duration of practice, level of education, environmental/religious influence on the program.

\section{METHODS}

This is a questionnaire-based prospective study. The survey was carried out by sending validated, structured selfadministered questionnaires to Oral and Maxillofacial Surgery trainees and specialists in tertiary hospitals in different parts (North, South, and West) of Nigeria. Questionnaires were worded in the English language, which is the official Nigerian language of communication. Participation was voluntary; confidentiality of participants' identity was also maintained. Ethical approval was sought and obtained from Institutional Ethical Board. Questionnaires were operator designed, based on information from the studies of Priyanka K et al, Rajesh $\mathrm{G}$ et al and Dedeke, A, A. et al. It contained a brief description of the study; this was followed by 22 closed-ended questions, which were divided into three sections, namely; Sociodemographics, perception, and attitude of 
Olasunkanmi Funmilola Kuye et.al. Perception and attitude of maxillofacial surgeons towards in-clinic counselling on tobacco cessation in tertiary hospitals in Nigeria.

respondents. Five questions assessed respondents' perception while five questions assessed their attitude, towards in clinic tobacco cessation counseling. The Questionnaires were distributed to three tertiary hospitals, while the rest were specialist hospitals, all accredited for the practice of maxillofacial surgery. Forty-four questionnaires were completed.

\begin{abstract}
ANALYSIS
Frequency and cross-tabulations of the obtained variables (age, sex, designation, and years of practice) were done, the inter-relationship between the variables and the attitude-based questions were analyzed using. IBM SPSS Statistics for Windows, released 2012, Version21.0. Amonk, NY: IBM Corp. The statistical significance of the variables was also tested using the Chi-square test, significance is maintained at $\mathrm{P} \leq$. 05 .
\end{abstract}

\section{RESULTS}

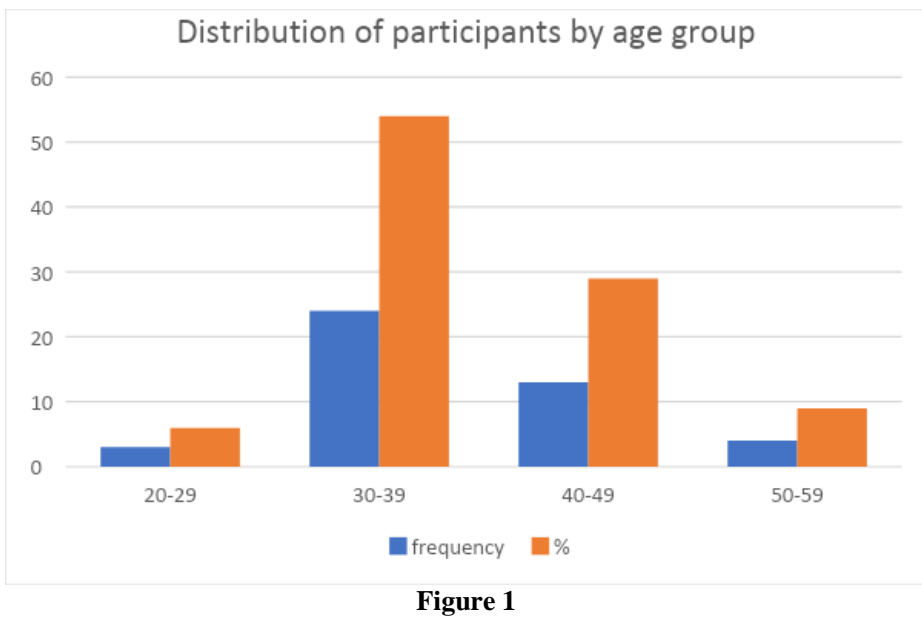

\section{Distribution of the participants professional status}

by cadre

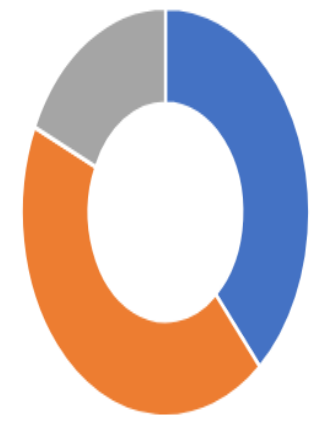

- Registrar $\|$ Senior Registrar $\quad$ | Consultant
Table 1 Description of the variables

\begin{tabular}{|c|c|c|}
\hline Variables & frequency & percent \\
\hline Male & 30 & 68.0 \\
\hline Female & 14 & 31.0 \\
\hline Total & 44 & 100 \\
\hline Religion & & \\
\hline Others & 1 & 2.0 \\
\hline Islam & 22 & 50.0 \\
\hline Christianity & 21 & 47.0 \\
\hline Years in practice & & \\
\hline $0-9$ & 16 & 36.0 \\
\hline $10-19$ & 20 & 45.0 \\
\hline $20-29$ & 8 & 18.0 \\
\hline Working Institutions & & \\
\hline General Hospital & 10 & 22.0 \\
\hline Specialist Hospital & 1 & 2.0 \\
\hline Teaching Hospital & 33 & 75.0 \\
\hline
\end{tabular}

Figure 2

Table 2 PERCEPTION RELATED QUESTIONS

\begin{tabular}{|c|c|c|c|c|}
\hline & Questions & Responses & Frequency & Percentage \\
\hline \multirow[t]{2}{*}{1} & Do you believe counseling on tobacco cessation can reduce oral cancer? & No & 7 & 15.0 \\
\hline & & yes & 37 & 84.1 \\
\hline \multirow[t]{2}{*}{2} & Do you feel using both professional training and religion will be more effective? & No & 14 & 31.0 \\
\hline & & Yes & 30 & 68.0 \\
\hline \multirow[t]{2}{*}{3} & Do you feel tobacco cessation is relevant to patient management? & No & 12 & 27.0 \\
\hline & & Yes & 32 & 72.0 \\
\hline \multirow[t]{2}{*}{4} & Do you think in-clinic counseling is impacting the patient? & No & 16 & 36.0 \\
\hline & & Yes & 28 & 63.0 \\
\hline \multirow[t]{2}{*}{5} & Are you constrained by time? & No & 14 & 31.0 \\
\hline & & Yes & 30 & 68.0 \\
\hline
\end{tabular}


A total of 44 individuals participated in the study, they include both maxillofacial trainees and specialists. Senior registrars accounted for the highest $19(43 \%)$ in the group of participants followed by the junior registrars 17 (38\%), the specialists were the lowest 8(18\%) (Figure 2). These participants were drawn from three cadres of hospitals in Nigeria (the General hospital 10(22\%), Specialist hospital 1(2\%), and the Teaching Hospital 33(75\%). Male to female ratio was $1: 2.1$, the mean age of the participants was 36.7 while the 30-39-yearolds age range accounted for the highest number 24(54\%) (Figure 1), the mean years in practice is 12.8. Christians accounted for 22(50\%) while Muslims were 21(47.0\%), the least was adherent of other religions $1(2.0 \%)$.

On the assessment of the perception of the participants (Table 2), all study participants agreed that there is a need for counseling on tobacco cessation, however, only $37(84.1 \%)$ believes that tobacco cessation counseling can reduce the prevalence of oral cancers. Thirty-two $(72.0 \%)$ had additional training on the in- clinic tobacco cessation counseling apart from the basic training received in dental school and the same percentage also believe that tobacco cessation is relevant to patient management in maxillofacial surgery. Most of the participants 30(68.0) believe that using both clinical and religious approach to in-clinic counseling can improve the outcome compared to $23(52 \%)$ that believes in religious means alone. $28(63.0 \%)$ believe that in-clinic counseling makes an impact on the patients while $30(63 \%)$ think that time constraint hinders effective counseling.

On the assessment of the relationship of the independent variables and the perception responses (Table $4 a, 4 b$ ), age groups, sex, religion, designation and the years in practice has a significant relationship with the participants 'perception related question ( $1 \&$ \& $)$ $\mathrm{p}=0.001$. The application of religion and professional techniques in counseling has a significant relationship with the age groups, religion, and years in practice with $\mathrm{p}<0.05$. The relevance of tobacco cessation counseling to patient management and sex was also statistically significant in the study.

Table 3

ATTITUDE RELATED QUESTIONS

\begin{tabular}{|l|l|l|l|l|}
\hline & Questions & Responses & Freq. & $\%$ \\
\hline i & Do you offer patients advice on tobacco cessation & Yes & 44 & 100 \\
ii & How often is the counseling done & regularly & 28 & 63.0 \\
& & occasionally & 16 & 36.0 \\
iii & As a maxillofacial surgeon is your religion influencing your counseling & No & 27 & 61.0 \\
& & Yes & 14 & 31.0 \\
iv & Any collaboration with other professionals to achieve the goal of tobacco cessation & No & 32 & 72.0 \\
& & Yes & No & 12 \\
v & Positive feedback from the patient & Yes & 15 & 34.1 \\
& & Not sure & 12 & 38.0 \\
& & & 27.0 \\
\hline
\end{tabular}

The participants' attitude to tobacco cessation counseling (Table 3 ) shows that all respondents offer a form of advice on tobacco cessation, 28(63\%) counsels' patients regularly while only $14(31 \%)$ agreed that their religion influences the counseling. The majority of the respondents $32(72 \%)$ are willing to collaborate with other professionals to achieve their goal of tobacco cessation counseling, 17(38\%) look forward to positive feedback from the patient while $12(27 \%)$ are not sure if they will need one.

Assessment of the relationship of the predictors and the responses to attitude questions (Table 5a,5b) shows that age and years in practice are significantly related to the regularity of counseling $\mathrm{p}<0.05$, this is also true for exposure of the study participants to counseling training outside of the regular dental curriculum and willingness to receive post counseling positive feedback from their patients. 
Olasunkanmi Funmilola Kuye et.al. Perception and attitude of maxillofacial surgeons towards in-clinic counselling on tobacco cessation in tertiary hospitals in Nigeria.

Age, designation, and years in practice were significantly related to the predisposition of the study participants to work with other professionals in tobacco cessation counseling of patients $\mathrm{p}<0.05$. No significant difference was found for sex, religion, and place of practice. While age, designation, years in practice, and place of practice have a significant relationship $\mathrm{p}=0.001$ with the influence of religion on counseling by the participants there was no significant difference among the religious groups and sex.

Table 4a

PERCEPTION

\begin{tabular}{|c|c|c|c|c|c|c|c|}
\hline Variables & & 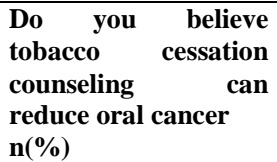 & $\begin{array}{l}\text { P- } \\
\text { Value }\end{array}$ & $\begin{array}{l}\text { Do you feel using both } \\
\text { professional training and } \\
\text { religion will be more } \\
\text { effective } \\
\text { n(\%) }\end{array}$ & $\begin{array}{l}\text { p- } \\
\text { Value }\end{array}$ & $\begin{array}{l}\text { Do you feel tobacco } \\
\text { cessation is relevant to } \\
\text { patient management } \\
n(\%)\end{array}$ & $\begin{array}{l}\text { p- } \\
\text { Value }\end{array}$ \\
\hline Age groups & $\begin{array}{l}20-29 \\
30-39 \\
40-49 \\
50-59 \\
\end{array}$ & $\begin{array}{l}3(8.1) \\
20(54.1) \\
11(29.7) \\
3(8.1) \\
\end{array}$ & 0.00 & $\begin{array}{l}2(6.7) \\
16(53.3) \\
10(33.3) \\
2(12.5) \\
\end{array}$ & 0.00 & $\begin{array}{l}2(6.3) \\
20(62.5) \\
9(28.1) \\
1(3.1) \\
\end{array}$ & 0.00 \\
\hline Sex & $\begin{array}{l}\text { Male } \\
\text { Female }\end{array}$ & $\begin{array}{l}26(70.3) \\
11(29.7)\end{array}$ & 0.00 & $\begin{array}{l}22(93.3) \\
8(26.7)\end{array}$ & 1.00 & $\begin{array}{l}22(68.8) \\
10(31.3)\end{array}$ & 0.02 \\
\hline Religion & $\begin{array}{l}\text { Others } \\
\text { Muslims } \\
\text { Christians } \\
\end{array}$ & $\begin{array}{l}1(2.7) \\
19(51.4) \\
17(45.9) \\
\end{array}$ & 0.00 & $\begin{array}{l}1(3.3) \\
15(50.0) \\
14(46.7) \\
\end{array}$ & 0.00 & $\begin{array}{l}1(3.1) \\
15(46.9) \\
16(50.0)\end{array}$ & 0.00 \\
\hline Designation & $\begin{array}{l}\text { Registrar } \\
\text { Senior } \\
\text { registrar } \\
\text { Consultant } \\
\end{array}$ & $\begin{array}{l}15(40.5) \\
16(43.2) \\
6(16.2) \\
\end{array}$ & 0.00 & $\begin{array}{l}15(50.0) \\
12(40.0) \\
3(10.0) \\
\end{array}$ & 6.00 & $\begin{array}{l}14(45.2) \\
14(45.2) \\
4(12.9) \\
\end{array}$ & 2.00 \\
\hline $\begin{array}{ll}\text { Years } & \text { in } \\
\text { Practice } & \end{array}$ & $\begin{array}{l}0-9 \\
10-19 \\
20-29 \\
\end{array}$ & $\begin{array}{l}14(37.8) \\
17(45.9) \\
6(16.2) \\
\end{array}$ & 0.00 & $\begin{array}{l}11(36.7) \\
15(50.0) \\
4(13.3) \\
\end{array}$ & 0.00 & $\begin{array}{l}13(40.6) \\
16(50.0) \\
3(9.1)\end{array}$ & 0.00 \\
\hline $\begin{array}{l}\text { Place of } \\
\text { practice }\end{array}$ & $\begin{array}{l}\text { General } \\
\text { hospital } \\
\text { Specialist } \\
\text { hospital } \\
\text { Teaching } \\
\text { hospital } \\
\end{array}$ & $\begin{array}{l}10(27.0) \\
0(0) \\
27(73.0)\end{array}$ & 7.00 & $\begin{array}{l}5(16.7) \\
0(0) \\
25(83.3)\end{array}$ & 4.00 & $\begin{array}{l}3(9.4) \\
1(3.1) \\
28(87.5)\end{array}$ & 12.02 \\
\hline
\end{tabular}

Table 4b

\begin{tabular}{|c|c|c|c|c|c|}
\hline Variables & & $\begin{array}{l}\text { Are you constrained by time? } \\
\text { n }(\%)\end{array}$ & p-value & $\begin{array}{l}\text { Does in clinic counsel impact the patient. } \\
\text { n }(\%)\end{array}$ & p-Value \\
\hline Age groups & $\begin{array}{l}20-29 \\
30-39 \\
40-49 \\
50-59 \\
\end{array}$ & $\begin{array}{l}3(10.0) \\
19(63.3) \\
6(20.0) \\
2(6.7) \\
\end{array}$ & 0.10 & $\begin{array}{l}2(7.1) \\
16(57.1) \\
8(28.6) \\
2(7.1) \\
\end{array}$ & 0.00 \\
\hline Sex & $\begin{array}{l}\text { Male } \\
\text { Female }\end{array}$ & $\begin{array}{l}22(73.3) \\
8(26.7)\end{array}$ & 1.00 & $\begin{array}{l}19(67.9) \\
9(32.1)\end{array}$ & 0.00 \\
\hline Religion & $\begin{array}{l}\text { Others } \\
\text { Muslims } \\
\text { Christians }\end{array}$ & $\begin{array}{l}1(3.3) \\
14(46.7) \\
15(50.0)\end{array}$ & 0.00 & $\begin{array}{l}1(3.5) \\
13(46.4) \\
14(50.0)\end{array}$ & 0.00 \\
\hline \multirow[t]{3}{*}{ Designation } & Registrar & $\begin{array}{l}12(40.0) \\
14(46.7) \\
4(13.3)\end{array}$ & 1.00 & $\begin{array}{l}12(42.9) \\
11(39.3) \\
5(17.9)\end{array}$ & 0.00 \\
\hline & Senior registrar & & & & \\
\hline & Consultant & & & & \\
\hline \multirow[t]{3}{*}{ Years in Practice } & $0-9$ & $\begin{array}{l}13(43.3) \\
14(46.7) \\
3(10.0)\end{array}$ & 0.04 & $\begin{array}{l}11(39.3) \\
14(50.0) \\
3(10.7)\end{array}$ & 0.00 \\
\hline & $10-19$ & & & & \\
\hline & $20-29$ & & & & \\
\hline \multirow[t]{3}{*}{ Place of practice } & General hospital & $\begin{array}{l}5(16.7) \\
0(0) \\
25(83.3)\end{array}$ & 0.00 & $\begin{array}{l}5(17.9) \\
0(0) \\
23(82.1)\end{array}$ & 3.08 \\
\hline & Specialist hospital & & & & \\
\hline & Teaching hospital & & & & \\
\hline
\end{tabular}


Olasunkanmi Funmilola Kuye et.al. Perception and attitude of maxillofacial surgeons towards in-clinic counselling on tobacco cessation in tertiary hospitals in Nigeria.

\section{ATTITUDE}

\begin{tabular}{|c|c|c|c|c|c|c|c|}
\hline \multicolumn{8}{|c|}{ Table 5a } \\
\hline Variables & & $\begin{array}{l}\text { Do you often } \\
\text { counsel } \\
\text { n }(\%)\end{array}$ & $\begin{array}{l}\text { p- } \\
\text { value }\end{array}$ & $\begin{array}{l}\text { Do you collaborate with } \\
\text { other professions? } \\
\text { n }(\%)\end{array}$ & $\begin{array}{l}\text { p- } \\
\text { value }\end{array}$ & $\begin{array}{l}\text { Positive feedback } \\
\text { from patients } \\
\text { n (\%) }\end{array}$ & $\begin{array}{l}\text { p- } \\
\text { value }\end{array}$ \\
\hline \multirow[t]{4}{*}{ Age } & $20-29$ & $\begin{array}{l}2(7.1) \\
15(53.6) \\
7(25.0) \\
4(14.3) \\
\end{array}$ & 0.00 & $\begin{array}{l}0(0) \\
5(41.7) \\
6(50.0) \\
1(8.3) \\
\end{array}$ & 0.00 & $\begin{array}{l}1(5.9) \\
11(64.7) \\
3(5.1) \\
2(11.8)\end{array}$ & 0.00 \\
\hline & $30-39$ & & & & & & \\
\hline & $40-49$ & & & & & & \\
\hline & $50-59$ & & & & & & \\
\hline \multirow[t]{2}{*}{ Sex } & Male & $\begin{array}{l}21(75.0) \\
7(25.0)\end{array}$ & 1.00 & $\begin{array}{l}6(50.0) \\
6(50.0)\end{array}$ & 2.00 & $\begin{array}{l}10(58.8) \\
7(41.2)\end{array}$ & 1.00 \\
\hline & Female & & & & & & \\
\hline \multirow[t]{3}{*}{ Religion } & Others & $\begin{array}{l}0(0) \\
12(42.9) \\
16(57.1)\end{array}$ & 3.00 & $\begin{array}{l}0(0.0) \\
10(83.3) \\
2(16.7)\end{array}$ & 7.00 & $\begin{array}{l}0(0) \\
10(58.8) \\
7(41.2)\end{array}$ & 5.00 \\
\hline & Muslims & & & & & & \\
\hline & Christians & & & & & & \\
\hline \multirow[t]{3}{*}{ Designation } & Registrar & $\begin{array}{l}10(35.7) \\
11(39.3) \\
7(25.0)\end{array}$ & 2.00 & $\begin{array}{l}4(33.3) \\
6(50.0) \\
2(16.7)\end{array}$ & 0.00 & $\begin{array}{l}8(47.1) \\
6(35.3) \\
3(17.4)\end{array}$ & 2.00 \\
\hline & $\begin{array}{l}\text { Senior } \\
\text { registrar }\end{array}$ & & & & & & \\
\hline & Consultant & & & & & & \\
\hline \multirow[t]{3}{*}{$\begin{array}{l}\text { Years in } \\
\text { practice }\end{array}$} & $0-9$ & $\begin{array}{l}12(42.9) \\
9(32.1) \\
7(25.0)\end{array}$ & 0.04 & $\begin{array}{l}2(16.7) \\
7(58.3) \\
3(25.0)\end{array}$ & 0.00 & $\begin{array}{l}5(29.4) \\
9(52.9) \\
3(17.6)\end{array}$ & 0.00 \\
\hline & $10-19$ & & & & & & \\
\hline & $20-29$ & & & & & & \\
\hline \multirow[t]{3}{*}{$\begin{array}{ll}\text { Place } & \text { of } \\
\text { practice }\end{array}$} & $\begin{array}{l}\text { General } \\
\text { hospital }\end{array}$ & $\begin{array}{l}7(25.0) \\
0(0) \\
21(75.0)\end{array}$ & 1.00 & $\begin{array}{l}6(50.0) \\
1(8.3) \\
5(41.7)\end{array}$ & 10.00 & $\begin{array}{l}6(35.3) \\
0(0) \\
11(64.7)\end{array}$ & 5.00 \\
\hline & $\begin{array}{l}\text { Specialist } \\
\text { hospital }\end{array}$ & & & & & & \\
\hline & $\begin{array}{l}\text { Teaching } \\
\text { hospital }\end{array}$ & & & & & & \\
\hline
\end{tabular}

Table 5b

\begin{tabular}{|c|c|c|c|c|c|}
\hline Variables & & $\begin{array}{l}\text { Any formal counseling training apart } \\
\text { from basic dental knowledge } \\
\text { n (\%) }\end{array}$ & $\begin{array}{l}\text { p- } \\
\text { value }\end{array}$ & $\begin{array}{l}\text { As a maxillofacial surgeon is your } \\
\text { religion influencing the counseling } \\
\text { n }(\%)\end{array}$ & $\begin{array}{l}\text { p- } \\
\text { value }\end{array}$ \\
\hline Age & $\begin{array}{l}20-29 \\
30-39 \\
40-49 \\
50-59\end{array}$ & $\begin{array}{l}4(14.3) \\
13(46.4) \\
8(28.7) \\
3(10.7)\end{array}$ & 0.00 & $\begin{array}{l}2(9.5) \\
10(47.6) \\
7(33.3) \\
2(9.5)\end{array}$ & 0.00 \\
\hline Sex & $\begin{array}{l}\text { Male } \\
\text { Female }\end{array}$ & $\begin{array}{l}19(82.6) \\
4(17.4)\end{array}$ & 3.00 & $\begin{array}{l}17(63.0) \\
4(19.0)\end{array}$ & 0.08 \\
\hline Religion & $\begin{array}{l}\text { Others } \\
\text { Islam } \\
\text { Christianity }\end{array}$ & $\begin{array}{l}1(6.7) \\
8(53.3) \\
6(40.0)\end{array}$ & 4.00 & $\begin{array}{l}0(0) \\
13(61.9) \\
8(38.1)\end{array}$ & 2.00 \\
\hline Designation & $\begin{array}{l}\text { Registrar } \\
\text { Senior } \\
\text { registrar } \\
\text { Consultants }\end{array}$ & $\begin{array}{l}15(46.9) \\
11(34.4) \\
6(18.8)\end{array}$ & 4.00 & $\begin{array}{l}9(42.9) \\
9(42.9) \\
\\
3(14.3)\end{array}$ & 0.00 \\
\hline $\begin{array}{ll}\text { Years } & \text { in } \\
\text { practice } & \end{array}$ & $\begin{array}{l}0-9 \\
10-19 \\
20-29 \\
\end{array}$ & $\begin{array}{l}2(16.7) \\
7(53.3) \\
3(25.0) \\
\end{array}$ & 0.00 & $\begin{array}{l}7(33.3) \\
9(42.9) \\
5(23.8) \\
\end{array}$ & 0.00 \\
\hline $\begin{array}{ll}\begin{array}{l}\text { Place } \\
\text { practice }\end{array} & \text { of }\end{array}$ & $\begin{array}{l}\text { General } \\
\text { hospital } \\
\text { Specialist } \\
\text { hospitals } \\
\text { Teaching } \\
\text { hospital }\end{array}$ & $\begin{array}{l}7(21.9) \\
0(0) \\
25(78.1)\end{array}$ & 2.00 & $\begin{array}{l}5(23.8) \\
0(0) \\
16(76.2)\end{array}$ & 0.00 \\
\hline
\end{tabular}

\section{DISCUSSION}

The tobacco epidemic has impacted negatively on public health globally including in Nigeria. Research and findings continue to reflect these negative effects of tobacco consumption on health as the number of affected people increases, the list 
of conditions caused by tobacco consumption also continues to increase.

All the participants in this study $(100 \%)$ agreed in this study that it is part of their responsibility to offer advice on smoking cessation similar to other studies (12-14), Previous studies show that dentists whose practices emphasize the surgical aspects of dentistry where smoking can negatively affect their therapeutic outcomes tend to emphasize smoking cessation compared to those whose specialties do not $(8,15,16)^{\circ}$ In addition, studies indicate that $71 \%$ of health professionals view themselves as role models for tobacco cessation thus a better opportunity to be involved in the counseling program $(12,13,17)$ In the United kingdom studies show that $63 \%$ of the health professionals were involved in smoking cessation advice out of $82 \%$ who thought that they have a major role $(13,17)$.

More than $80 \%$ of the participants indicated that in-clinic tobacco cessation counseling will reduce the prevalence of oral malignancies, this agrees with other researches that postulates that quitting smoking helps reduce the risk of oral cancer by $50 \%$ in five years, they suggested that reducing cancer risk factors is the most effective tool in decreasing associated morbidity and mortality $(8,11)$. Impairment of both surgical and traumatic wound healing of tobacco smoking patients because of the peripheral vasoconstrictor influence can also be eliminated or reduced to the barest minimum $(4,8,16)$.

A larger percentage of the doctors in the study are located in the teaching hospitals, the junior residents are also more in number and involved in the program compared to the senior doctors (the specialist). The teaching Hospitals are established training centers and the awareness to specialize in Nigeria has grown lately among dental surgeons. There is no indication in the study that senior doctors are likely to be more involved than junior doctors. Though junior doctors have the numbers and likely have more time interacting with the patients, the skills with the experience to manage the patient lies more with the senior doctors.

A study by Mitra et al (13), indicated that senior dental professionals were more likely to advise tobacco cessation than others. This view of senior professionals was attributed to their experience in treating patients.

Many studies indicate that tobacco cessation training is associated with higher intervention rates and increased selfefficacy $(12,18)$. Although some of the participants claimed to have further training apart from the dental school acquired basic knowledge on tobacco cessation counseling, however, several never had any such additional training which may explain the poor patient feedback demand and the low motivation in working with other specialties. Updates courses and training in tobacco cessation programs improve the professionals' knowledge, confidence and provide them with materials for educating the patients on the cessation program $(14,16,19)$ which may include follow-up plans and multidisciplinary management $(14,16)$. In 2006, the Commonwealth Dental Association agreed that training in tobacco control should be provided for basic dental undergraduates to enable them to inform patients of the risks of tobacco use and support their patients in quitting smoking $(13,18)$. Furthermore, a cross-sectional survey of east Texas dentists found that frequent updates in knowledge and training in the use of the recommendations of Treating Tobacco Use and Dependence, specifically use of the 5A's (Ask Advice, Access, Assist, and Arrange), was significantly associated with adherence to cessation protocols and time spent counseling (18)

Time was noted to be a major barrier to effective counseling in this study, most believe that the in-clinic time spent in advising and counseling patients was not enough (13). Large patient load, limited skill hands to manage patients, and small clinic room space are some of the likely 
factors affecting the required time needed by the surgeons. Other studies that have surveyed general dental practitioners indicate that lack of time often seems to be the most important barrier(16).

Religions are many and varied, but most value human well-being highly and so do not approve of tobacco use, even though they do not prohibit it entirely. In recent years, researchers had paid more attention to the subject of religion and health, including drug and tobacco use (20). Religious groups have long instructed members on what is permissible concerning diet, hygiene, exercise, and alcohol, drug, or tobacco use (21)

The study participants belong to different religious sects, a factor that strongly influences the actions, perceptions, and attitudes of people in the Nigeria setting. There is a high indication that the various religious beliefs help the individual participants to be more committed to cessation counseling and to agree on the need for tobacco cessation counseling as seen in this study. Studies had also documented that higher levels of religious belief and activity have been associated with lower rates of tobacco use $(21,22)$.

\section{CONCLUSION}

This study has shown that there is a need for a tobacco cessation program within the health institutions as it is an avenue to stop/reduce the associated sequelae of tobacco use. It is, therefore, necessary for the policymakers to ensure more training programs for maxillofacial surgeons and other dental health workers.

\section{Conflict of Interest:} this study

We declare no conflict of interest in

\section{Acknowledgement: None}

Source of Funding: None

Ethical Approval: Approved

\section{REFERENCES}

1. Shaik SS, Doshi D, Bandari SR, Madupu PR, Kulkarni S. Tobacco use cessation and prevention - A review. J Clin Diagnostic Res. 2016;10(5): Z E13-7.

2. Dedeke AA, Popoola OA, Adebiyi AO, Asuzu MC. Tobacco Cessation Services and Related Challenges Among Dentists in Southwest Nigeria. Ann Ibadan Postgrad Med. 2018;16(2):125-30.

3. Oyewole BK, Animasahun VJ, Chapman HJ. Tobacco use in Nigerian youth: A systematic review. PLoS One. 2018;13(5):1-13.

4. Article R, Moharil RB, Dive A. Tobacco, and Health - A Review. 2019;3(6):20-4.

5. Klemp I, Steffenssen M, Bakholdt V, Thygesen T, Sørensen JA. Counseling Is Effective for Smoking Cessation in Head and Neck Cancer Patients-A Systematic Review and Meta-Analysis. J Oral Maxillofac Surg [Internet]. 2016;74(8): 1687-94. Available from: http://dx.doi.org/10.1016/j.joms.2016.02.00 3

6. Rajesh G, Pinto AS, Binnal A, Naik D, Rao A. Counselling as a tool for tobacco cessation in a dental institution: Insights from India. Asian Pacific J Cancer Prev. 2019;20(8):2541-50.

7. Sweet JB. Discussion. The Relationship of Cigarette Smoking to Impaired Intraoral Wound Healing: A Review of Evidence and Implications for Patient Care. J Oral Maxillofac Surg. 1992;50(3):239-40.

8. Balaji S. Tobacco smoking and surgical healing of oral tissues: A review. Indian J Dent Res. 2008;19(4):344-8.

9. Albert D, Ward A. Tobacco cessation in the dental office. Dent Clin North Am [Internet]. 2012;56(4):747-70. Available from:

http://dx.doi.org/10.1016/j.cden.2012.07.00 4

10. Vinod V, Taneja L, Mehta P, Koduri S. Dental professionals as a counselor for tobacco cessation: A survey. J Indian Acad Oral Med Radiol. 2017;29(3):209.

11. Omaña-Cepeda C, Jané-Salas E, EstrugoDevesa A, Chimenos-Küstner E, LópezLópez J. Effectiveness of dentist's intervention in smoking cessation: A review. J Clin Exp Dent. 2016;8(1):e78-83.

12. Maheswaran T, Mohanapriya S, Ganapathy $\mathrm{N}$, Ilayaraja $\mathrm{V}$, Dineshshankar J, 
Olasunkanmi Funmilola Kuye et.al. Perception and attitude of maxillofacial surgeons towards in-clinic counselling on tobacco cessation in tertiary hospitals in Nigeria.

Yoithapprabhunath $\mathrm{T}$, et al. Attitudes, practices, and perceived barriers in smoking cessation among the dental surgeons: A pilot study. J Indian Acad Dent Spec Res. 2017;4(2):38.

13. Mitra DK, Pawar SD, Mandal A, Shah RA, Rodrigues SV, Desai AB, et al. Attitudes of dental professionals toward tobacco use. Vol. 19, Journal of Indian Society of Periodontology. 2015. p. 317-21.

14. Bhat N, Jyothirmai-Reddy J, Gohil M, Khatri M, Ladha M, Sharma M. Attitudes, Practices and Perceived Barriers in Smoking Cessation among Dentists of Udaipur City, Rajasthan, India. Addict Heal [Internet]. 2014;6(1-2):73-80. Available from: http://www.ncbi.nlm.nih.gov/pubmed/25140 220\%0Ahttp://www.pubmedcentral.nih.gov/ articlerender.fcgi?artid=PMC4137435

15. Oyapero A, Olatosi O, Olagundoye O. Are Nigerian oral health workers overlooking opportunities to promote interventions for tobacco smoking cessation? Popul Med. 2021;3(February):1-7.

16. Allard RH. Tobacco and oral health: attitudes and opinions of European dentists; a report of the EU working group on tobacco and oral health. Int Dent J. 2000; 50(2):99-102.

17. John JH, Thomas D, Richards D. Smoking cessation interventions in the Oxford region: changes in dentists' attitudes and reported practices 1996 - 2001. 2003;2705.
18. Kathleen VR, Daniel LJ, Karen MC. Tobacco Cessation Education for Dentist: An Evaluation of the Lecture Format. J. Cancer Edu.2010:25(3).282-284. doi: 10.1007/s13187-010-0042-9

19. Mullen KA, Manuel DG, Hawken SJ, Pipe AL, Coyle D, Hobler LA, et al. Effectiveness of a hospital-initiated smoking cessation program 2-year health and healthcare outcomes. Tob Control. 2017; 26(3): 293-9.

20. Garrusi B, Nakhaee N. Religion and smoking: A review of recent literature. Int $\mathbf{J}$ Psychiatry Med. 2012;43(3):279-92.

21. H.G. K, L.K. G, H.J. C, J.C. H, D.B. L, D.G. B. The relationship between religious activities and cigarette smoking in older adults. Journals Gerontol - Ser A Biol Sci Med Sci [Internet]. 1998;53(6): M 426-34. DOI:

http://dx.doi.org/10.1093/gerona/53A.6.M4 26

22. Hussain M, Walker C, Moon G. Smoking and Religion: Untangling Associations Using English Survey Data. J Relig Health. 2019;58(6):2263-76.

How to cite this article: Kuye OF, Olagundoye O, Ladeji AM et.al. Perception and attitude of maxillofacial surgeons towards in-clinic counselling on tobacco cessation in tertiary hospitals in Nigeria. Int J Health Sci Res. 2021; 11(10): 177-185. DOI: https://doi.org/10.52403 /ijhsr.20211023 